\title{
Physical interaction of STAT1 isoforms with TGF- $\beta$ receptors leads to functional crosstalk between two signaling pathways in epithelial ovarian cancer
}

Xiaoling Tian', Wencai Guan ${ }^{1}$, Lingyun Zhang ${ }^{1,2}$, Wenwen Sun ${ }^{1}$, Daibing Zhou ${ }^{1,2}$, Qunbo Lin ${ }^{1,2}$, Weimin Ren ${ }^{1,2}$, Lubna Nadeem ${ }^{3}$ and Guoxiong $\mathrm{Xu}^{1,2^{*}}$

\begin{abstract}
Background: The signal transducer and activator of transcription (STAT) and transforming growth factor- $\beta$ (TGF- $\beta$ ) signaling pathways play important roles in epithelial ovarian cancer (EOC). However, the mechanism of crosstalk between two pathways is not completely understood.

Methods: The expression of STAT1 protein was detected by tissue microarray and immunoblotting (IB). The interaction of STAT1 isoforms with TGF- $\beta$ receptors was confirmed by immunoprecipitation and IB. The effect of TGF- $\beta$ signaling on STAT1 activation was examined in EOC and non-tumorous HOSEpiC cells treated with TGF- $\beta 1$ in the presence or absence of the inhibitor of TGF- $\beta$ type I receptor. The gain-of-function and loss-of-function approaches were applied for detecting the role of STAT1 on EOC cell behaviours.

Results: The high level of STAT1 was observed in patients with high-grade serous EOC. STAT1 expression was higher in ovarian cancer cells than noncancerous cells. TGF- $\beta 1$ activated the STAT1 pathway by inducing the phosphorylation of STAT1 $a$ on S727 residue. The full-length STAT1a and the truncated STAT1 $\beta$ directly interacted with TGF- $\beta$ receptors (ALK1/ALK5 and T $\beta R R I I)$, which was mediated by TGF- $\beta 1$. STAT1 $a$ and STAT1 $\beta$ blocked the activation of the TGF- $\beta 1$ signaling pathway in EOC cells by reducing Smad2 phosphorylation. STAT1 overexpression induced EOC cell proliferation, migration, and invasion; whereas its inhibition enhanced TGF- 31 -induced phospho-Smad2 and suppressed EOC cell proliferation, migration, and invasion.
\end{abstract}

Conclusions: Our data unveil a novel insight into the molecular mechanism of crosstalk between the STAT1 and TGF- $\beta$ signaling pathways, which affected the cancer cell behavior. Suppression of STAT1 may be a potential therapeutic strategy for targeting ovarian cancer.

Keywords: Activin receptor-like kinase, Cell proliferation, Crosstalk, Cytokine, Growth factor, Receptor, Signal transduction, Smad, TRRII, Tumorigenesis

\footnotetext{
* Correspondence: guoxiong.xu@fudan.edu.cn

${ }^{1}$ Center Laboratory, Jinshan Hospital, Fudan University, 1508 Longhang Road,

Shanghai 201508, People's Republic of China

²Department of Oncology, Shanghai Medical College, Fudan University,

Shanghai 200032, China

Full list of author information is available at the end of the article
}

(c) The Author(s). 2018 Open Access This article is distributed under the terms of the Creative Commons Attribution 4.0 International License (http://creativecommons.org/licenses/by/4.0/), which permits unrestricted use, distribution, and reproduction in any medium, provided you give appropriate credit to the original author(s) and the source, provide a link to the Creative Commons license, and indicate if changes were made. The Creative Commons Public Domain Dedication waiver (http://creativecommons.org/publicdomain/zero/1.0/) applies to the data made available in this article, unless otherwise stated. 


\section{Background}

Epithelial ovarian cancer (EOC) is a female malignant disease. The mechanism of the occurrence and development of EOC is complex. Cytokines and growth factors may play important roles in ovarian tumorigenesis. The signal transducer and activator of transcription 1 (STAT1) is one of the members of STAT family and functions as a signal messenger, transcription factor, and immune modulator, participating in cellular processes including cell proliferation, differentiation, apoptosis, and immunosurveillance [1-3]. STAT1 has two isoforms, a full-length STAT1 $\alpha$ and a truncated STAT1 $\beta$. STAT1 $\alpha$ carries two phosphorylation sites, tyrosine 701 (Y701) and serine 727 (S727). The latter is located at a C-terminal trans-activation domain (TAD) [4]. STAT1 $\beta$ is expressed at a low level and lacks the TAD but is efficiently phosphorylated on Y701 $[5,6]$. The canonical signaling pathway of STAT1 is triggered by Janus kinase (JAK) upon ligands, such as interferon- $\gamma($ IFN- $\gamma$ ), stimulation [7]. The phosphorylated and activated STAT1 then translocate into the nucleus and regulates the expression of target genes. For example, IFN- $\gamma$ can enhance the expression of Smad7 through the JAK1/STAT1 signaling pathway [8]. Smad7 is an inhibitory Smad which prevents the interaction of Smad3 with transforming growth factor- $\beta$ (TGF- $\beta$ ) receptor [9].

It has been shown that TGF- $\beta$ plays an important role in ovarian cancer $[10,11]$. The canonical TGF- $\beta$ signaling pathway acts through the intracellular transducer proteins such as receptor-activated Smad (R-Smad). Upon TGF- $\beta$ binding, the constitutively activated type II receptor (TRRII) recruits and phosphorylates the type I receptor (T $\beta R I)$ on the cell surface $[12,13]$. T $\beta R I$, also known as activin receptor-like kinase (ALK), has seven members [14]. ALK5 (TGFBRI, expressed in most types of cells) and ALK1 (ACVRL1, expressed mainly in endothelial cells) are two subtypes of T $\beta R I$ for human TGF- $\beta$ [15]. TGF- $\beta 1$-activated ALK5 and/or ALK1 further recruit and phosphorylate R-Smads, such as Smad2/3 by ALK5 and Smad1/5/8 by ALK1. The phosphorylated and activated R-Smads then form a complex with common Smad (Co-Smad) Smad4 and the resulting complex then translocates into the nucleus where it acts as a transcription factor by binding to the promoter of a target gene to regulate its expression [16]. Smad6 and Smad7 are two inhibitory Smads (I-Smads) which prevent or inhibit Smad2/3 phosphorylation and nuclear translocation, hence suppressing their downstream function [17].

The interference between STAT1 and TGF- $\beta$ signaling has been reported previously $[8,18,19]$. For instance, a bipyridyl compound CaeA can enhance TGF- $\beta /$ Smad3 signaling by suppressing IFN- $\gamma / \mathrm{STAT} 1$ signaling in regulatory T cells [18]. An inhibitory action of STAT1 on
TGF- $\beta$ signaling is via the induction of inhibitory Smad7 [8]. On the other hand, TGF- $\beta 1$ suppresses IFN- $\gamma$ induced STAT1 signaling through the promotion of STAT1 and its inhibitor protein interaction [19]. All these suggest that the crosstalk between two pathways is the downstream event of receptor activation and no exact mechanism of interference from each other is explored at the receptor level. The physical interaction of STAT1 with the signaling components of TGF- $\beta$ is never speculated.

Our recent study using high-throughput luminescencebased mammalian interactome mapping technology showed that STAT1 as a potential binding protein is one of the novel interactors of the TGF- $\beta 1$ receptor [20]. The current study validated for the first time that STAT1 isoforms directly interacts with TGF- $\beta$ receptors and determined the consequence of this interaction particularly on the downstream signaling of TGF- $\beta 1$. Meanwhile, we determined whether TGF- $\beta 1$ activates STAT1 and STAT1/TGF- $\beta$ receptor complex. The expression of STAT1 in EOC and the function of STAT1 on EOC cell behaviours were also examined.

\section{Methods}

\section{Patients and ovarian tissue preparation}

Human fresh ovarian tissue samples were obtained with informed consent from patients. The study on human subjects was approved by the Ethics Committee of Jinshan Hospital, Fudan University. A total of 20 ovarian samples were collected from patients who underwent cytoreductive surgery ( 5 normal samples from patients with non-ovarian tumor and 15 ovarian tumor samples, including 6 benign, 3 borderline, and 6 malignant tumors) with median age 50 years (range 25-70 years) at Jinshan Hospital from January, 2013 to January, 2016. None of the patients had received chemotherapy or radiotherapy before surgery.

\section{Tissue microarray and immunohistochemistry}

A human ovarian tissue microarray was obtained from Alena Biotechnology Co., Ltd. (Cat\# OV1005a, Xi'an, Shanxi, China). All tissues were $10 \%$ formalin-fixed and paraffin-embedded. A total of 100 ovarian tissue specimens (20 normal controls and 80 ovarian tumors) were examined by immunohistochemistry (IHC). Among 100 specimens in a slide, seven came off during the IHC staining process. In the end, 20 normal controls (3 from normal ovaries and 17 from adjacent normal ovary tissues) with median age 48.5 years (range 19-63 years) and 73 ovarian tumors (12 benign, 7 borderline, 44 malignant, 10 metastatic) with median age 49.0 years (range $17-75$ years) were statistically analyzed.

After blocking with 10\% normal goat serum (Fuzhou Maixin Biotech Co., Ltd., Maixin Bio, Fuzhou, Fujian, China), the sections were incubated with rabbit 
monoclonal antibodies against STAT1 (Cat\# 9175), pSTAT1-Y701 (Cat\# 9167) and pSTAT1-S727 (Cat\# 8826) (Cell Signaling Technology, Inc., Danvers, MA, USA), respectively, overnight, followed by incubation with biotinylated anti-rabbit secondary antibody (Cell Signaling Technology) at room temperature for $1 \mathrm{~h}$. Scoring of STAT1 immunoreactive staining was performed by two independent examiners without any prior view of patient's clinical data and classified as described previously using staining index (SI) system [21].

\section{Cell culture}

Human epithelial ovarian cancer cell lines (OVCAR-3 and SK-OV-3) and human embryonic kidney cell line (HEK-293 T) were obtained from American Type Culture Collection (ATCC, Manassas, VA, USA). Non-tumorous human ovarian surface epithelial cells (HOSEpiC) were obtained from ScienCell Research Laboratories (Carlsbad, CA, USA). HOSEpiC and OVCAR-3 were cultured in RPMI-1640 medium (HyClone, Thermo Fisher Scientific Inc., Beijing, China), whereas SK-OV-3 and 293 T cells were cultured in Dulbecco's Modified Eagle's Medium (DMEM) (HyClone), supplemented with 10\% fetal bovine serum (FBS) (Invitrogen, Carlsbad, CA, USA).

\section{Treatment with TGF- $\beta 1$ and inhibitor of TGF- $\beta$ type I receptor kinase}

Cells were seeded into 6 -well plate at $5 \times 10^{5}$ cells/well for $24 \mathrm{~h}$ and then treated with TGF- $\beta 1(0,0.1,1$ or $10 \mathrm{ng} / \mathrm{ml}$, R\&D Systems, Minneapolis, MN, USA) for $24 \mathrm{~h}$ or $10 \mathrm{ng} / \mathrm{ml}$ of TGF- $\beta 1$ for a time period as indicated. In order to block the TGF- $\beta$ signaling, cells were pre-treated with an inhibitor of TGF- $\beta$ type I receptor kinase $(10 \mu \mathrm{M}$ SB-431542, Sigma, Saint Louis, MO, USA) for $30 \mathrm{~min}$, followed by $10 \mathrm{ng} / \mathrm{ml}$ of TGF- $\beta 1$ treatment for $24 \mathrm{~h}$.

\section{Quantitative real-time polymerase chain reaction (qRT-PCR)}

Total RNA was extracted from cells and tissues using the RNeasy Mini Kit (Qiagen, Gaithersburg, MD, USA) according to the manufacturer's instruction. Fivehundred nanogram of total RNA was reverse-transcribed using a Transcriptor First Strand cDNA Synthesis Kit (Roche Diagnostics, Indianapolis, IN, USA). The primers for total STAT1, STAT1 $\alpha$, STAT1 $\beta$, and $\beta$-actin (shown in Additional file 1: Table S1) were synthesized (GenePharma Co. Ltd., Shanghai, China). PCR amplification was performed using a Power SYBR Green PCR Master Mix Kit by 7300 Real-Time PCR System (Applied Biosystems, Foster City, CA, USA) according to the manufacturer's recommendations.

\section{Transfection of small interfering RNA}

Cells were seeded into 6 -well plate at $2.5 \times 10^{5}$ cells/well and transfected with $1 \mu \mathrm{g}$ of human STAT1-small interfering RNA (STAT1-siRNA) or scramble non-specific control siRNA (NC-siRNA) (GenePharma Co. Ltd; Additional file 1: Table S1) using X-tremeGENE siRNA transfection reagent (Roche Diagnostics) according to the manufacturer's instruction, followed by incubation for the indicated time.

\section{Generation of constructs}

TGF- $\beta$ receptor constructs were used as described previously [20]. STAT $1 \alpha$ and STAT $1 \beta$ constructs were generated by inserting the PCR products into a mammalian expression vector. Briefly, the cDNA encoding STAT $1 \alpha$ or STAT $1 \beta$ was amplified by PCR using the Pfu Ultra II Fusion HS DNA Polymerase (Stratagene, Agilent Technologies, CA, USA) with specific primers (shown in Additional file 1: Table S1). After purification of PCR, the product was inserted into the Kpn I and Sac II sites of $\mathrm{pcDNA} 4 / \mathrm{TO} / \mathrm{myc}-\mathrm{His}$ (B) vector (Invitrogen). Two plasmids named as pStat $1 \alpha$-myc and pStat $1 \beta$-myc were generated and the presence of insert was confirmed by restriction enzyme digestion as well as by sequencing.

Transient transfection and co-immunoprecipitation (co-IP) HEK-293 T cells were seeded into 6-well plate at $2.5 \times 10^{5}$ cells/well and were transfected or co-transfected with $4 \mu \mathrm{g}$ receptor plasmid (ALK1-HA, ALK5-HA or T $\beta$ RII-HA) and/or STAT1 plasmid (Stat1 $\alpha$-myc or Stat1 $\beta$-myc) using DNA Transfection Reagent (GBC lifetech, Miami, FL, USA). After incubation for $48 \mathrm{~h}$, cells were lysed with Pierce RIPA Buffer (Thermo Scientific, Rockford, IL, USA) supplemented with phosphatase inhibitor (KeyGEN BioTECH, Nanjing, Jiangsu, China) and PMSF (Beyotime, Haimen, Jiangsu, China) on ice for $20 \mathrm{~min}$. Cell lysates (500 $\mu \mathrm{g}$ of total proteins) were then incubated with $5 \mu \mathrm{l}$ anti-Myc IP Affinity gel or anti-HA IP Affinity gel (GBC lifetech) overnight at $4{ }^{\circ} \mathrm{C}$ according to the manufacturer's instruction. After extensive washing, bound proteins were eluted with $4 \mathrm{X}$ sample buffer. Eluate and input proteins were then subjected to immunoblotting.

\section{Immunoblotting (IB)}

Cells were lysed using Pierce RIPA buffer supplemented with 1\% PMSF and phosphatase inhibitors (KeyGEN BioTECH). Protein concentration was measured using the BCA Protein Assay (Thermo Scientific). Equal amounts of protein were separated on 10\% SDS-PAGE and transferred to a PVDF membrane (Millipore, Billerica, MA, USA). After blocking, the membrane was incubated with a primary antibody at $4{ }^{\circ} \mathrm{C}$ overnight and subsequently incubated with horseradish peroxidaseconjugated goat anti-rabbit or anti-mouse IgG (Cell 
Signaling Technology, Inc., Danvers, MA, USA) for $1 \mathrm{~h}$ at room temperature. The following primary antibodies were used: rabbit monoclonal anti-STAT1, anti-pSTAT1-Y701, anti-pSTAT1-S727, mouse monoclonal anti-Smad2, rabbit polyclonal anti-pSmad2, anti- $\beta$-actin (Cell Signaling Technology), rabbit polyclonal anti-HA and anti-c-Myc (Santa Cruz Biotechnology, Inc., CA, USA). Signals were detected using Immobilon ${ }^{\mathrm{TM}}$ Western Chemiluminescent HRP Substrate (Millipore) and quantified using Tanon-4500 Gel Imaging System with GIS ID Analysis Software v4.1.5 (Tanon Science and Technology Co., Ltd., Shanghai, China).

\section{Cell proliferation, migration, and invasion assays}

For the cell proliferation assay, cells were seeded into 96well culture plate at a density of $3 \times 10^{3}$ cells/well and incubated for $24 \mathrm{~h}$, followed by transfection with STAT1 plasmids or STAT1-siRNA or their counterpart controls in the absence or presence of $10 \mathrm{ng} / \mathrm{ml}$ of TGF- $\beta 1$ for 48 h. Cell proliferation was measured by the Cell Proliferation Reagent (WST-1 kit, Roche) according to the manufacturer's instruction. The signal was read by a microplate reader (BioTek Epoch, Winooski, VT, USA) at $450 \mathrm{~nm}$.

For the migration assay, SK-OV-3 cells were seeded into 6 -well plate at a density of $3 \times 10^{5}$ cells/well and cultured for $24 \mathrm{~h}$. The cell monolayer was then scraped using a pipette tip to make a scratch wound. After washing, cells were transfected with STAT1 plasmids or STAT1-siRNA as well as their counterpart controls and incubated for 24, 48, and $72 \mathrm{~h}$. Cell migration was determined by wound healing. Images of the wound were obtained by photography and the gap widths were measured and analyzed.

Cell invasion was performed in a plate with a Transwell containing a porous membrane (pore size $8 \mu \mathrm{m}$, Costar, Corning Incorporated, New York, NY, USA) coated with Matrigel (final concentration of $250 \mu \mathrm{g} / \mathrm{ml} /$ well, BD Biosciences, Bedford, MA, USA). After transfection of SKOV-3 cells with STAT1 plasmids or STAT1-siRNA or their counterpart controls for $24 \mathrm{~h}$, the transfected cells were seeded on the top chamber of Transwells without serum at a density of $1 \times 10^{4}$ cells/well. The bottom chamber was supplemented with $10 \%$ FBS as a chemoattractant. After incubation at $37{ }^{\circ} \mathrm{C}$ for $48 \mathrm{~h}$, the non-invaded cells were removed by wiping the upper layer of the chamber. The invaded cells on the bottom surface were fixed with $4 \%$ paraformaldehyde and stained with 5\% Crystal Violet Staining Solution (Beyotime). The cell number was counted in three random fields under a light microscope (BX43, Olympus, Tokyo, Japan). All experiments were repeated at least three times.

\section{Statistical analysis}

Data were analyzed using GraphPad Prism 5 (GraphPad Software Inc., San Diego, CA, USA) and SPSS Statistics
21 for Windows (SPSS, Chicago, IL, USA). For comparison between two groups or multiple comparisons in treatment experiments, a Student's t-test or one-way ANOVA was applied. Results are presented as the mean \pm the standard error of the mean (SEM). The difference at $P<0.05$ was considered statistically significant.

\section{Results}

STAT1 expression is elevated in human high-grade serous epithelial ovarian cancer

We compared the expression of STAT1 and its phosphorylated forms (pSTAT1-Y701 and pSTAT1-S727) in normal ovarian tissues and tissues of benign tumor, serous borderline tumor, and high-grade serous malignant carcinoma via immunohistochemistry. Tissue microarray showed that the positive staining of total STAT1 and phospho-STAT1 on Y701 and S727 residues in serous ovarian borderline and malignant tumors only (Fig. 1a). The tissues from borderline as well as malignant tumors showed significantly elevated levels of STAT1 as well as pSTAT1-Y701, and pSTAT1-S727 compared to the normal ovarian tissue (Fig. 1b). An array of IHC conducted on different types of ovarian cancer tissues such as serous, mucinous, endometrioid, transitional cell and metastatic tumors. We found that the expression of total STAT1, pSTAT1-Y701, and pSTAT1-S727 was elevated in all except the mucinous malignant tumors (Additional file 2: Figure S1). The comparison of the immunoreactive score between different types of the tissue showed significant differences $(P<0.05$; Additional file 1 : Table S2).

We further investigated the association of STAT1 expression with the clinicopathological features of patients with epithelial-type ovarian tumors. We found that the expression of STAT1 was not associated with the age ( $\leq 45$ vs. $>45$ years), histological type, lymph node metastasis, and clinical stages $(P>0.05$; Table 1$)$. However, when we compared the grade of serous carcinoma, a main type of EOC, we found that the total STAT1 but not the phospho-forms was significantly different between high-grade and low-grade serous carcinoma $(P=0.031$; Table 1$)$. The positive staining of total STAT1 was observed in all high-grade serous carcinoma $(n=5)$.

Based on the SI system, we classified STAT1 expression into positive and negative categories. Statistical analysis showed that the positivity of pSTAT1-Y701, pSTAT1-S727, and total STAT1 expression was significantly higher in ovarian borderline and malignant tumors compared with normal ovarian tissue (all $P<0.05$; Additional file 1: Table S3).

The overexpression of STAT1 at mRNA and protein levels was further confirmed in freshly isolated ovarian tissues by qRT-PCR and immunoblotting. Using specific primers recognizing to STAT1 isoforms, we found that 

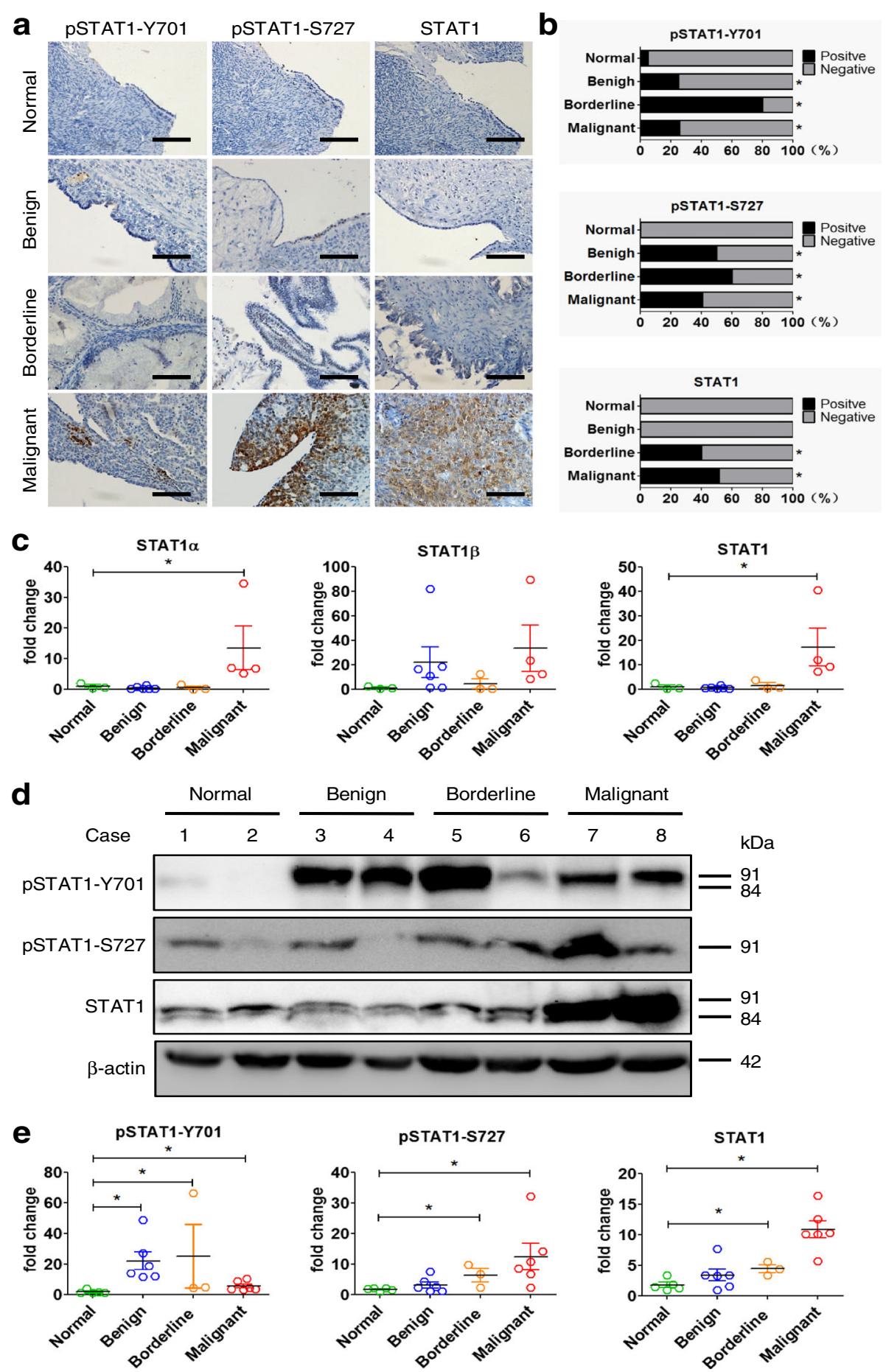

Fig. 1 STAT1 is overexpressed in human epithelial ovarian cancer. a Immunohistochemical staining of STAT1 in ovarian tissues. A brown color in epithelial cells is considered as a positive staining. Representative images of pSTAT1-Y701, pSTAT1-S727, and total STAT1 expression in normal ovarian tissue (Normal), benign tumor (Benign), serous borderline tumor (Borderline), and high-grade serous carcinoma (Malignant) are shown. Original magnification, $\times$ 400; scale bar, $100 \mu \mathrm{m}$. b The case rate of pSTAT1-Y701, pSTAT1-S727, and STAT1 positivity and negativity. For comparison between two groups, $x^{2}$ test was applied. $\mathbf{c}$ STAT1 mRNA expression detected by quantitative RT-PCR. The expression of STAT1a and total STAT1 was higher in ovarian serous malignant tumors (Normal, $n=3$; Benign, $n=6$; Borderline, $\mathrm{n}=3$; Malignant, $n=4$ ). $\mathbf{d}$ The expression of total STAT1, pSTAT1Y701, and pSTAT1-S727 detected by immunoblotting. Representative images are shown. STAT1a, 91 kDa; STAT1ß, 84 kDa. e Densitometric analysis of the gels in (d) (Normal, $n=5$; Benign, $n=6$; Borderline, $n=3$; Malignant, $n=6$ ). ${ }^{*}, P<0.05$ compared to normal tissue 


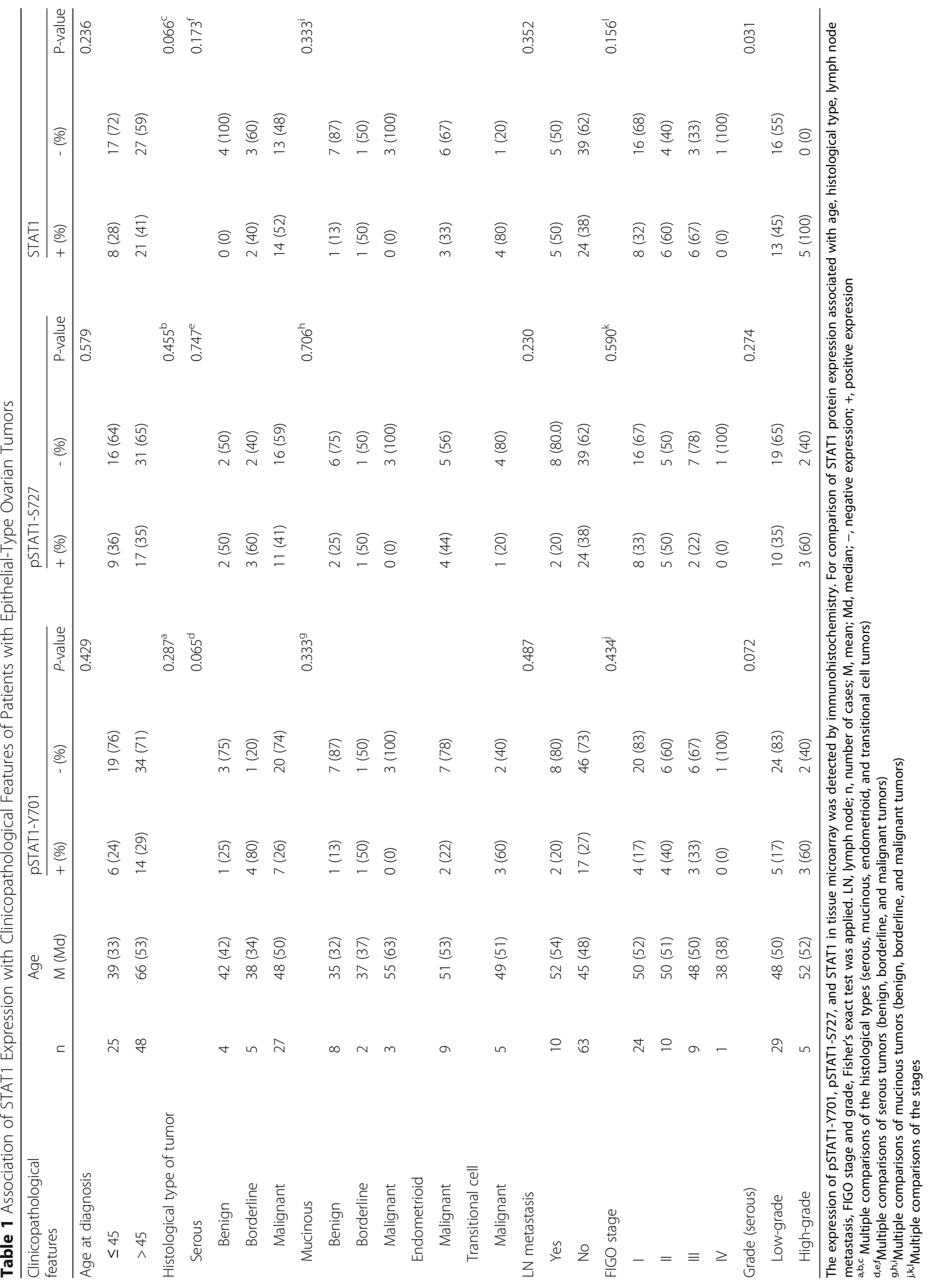




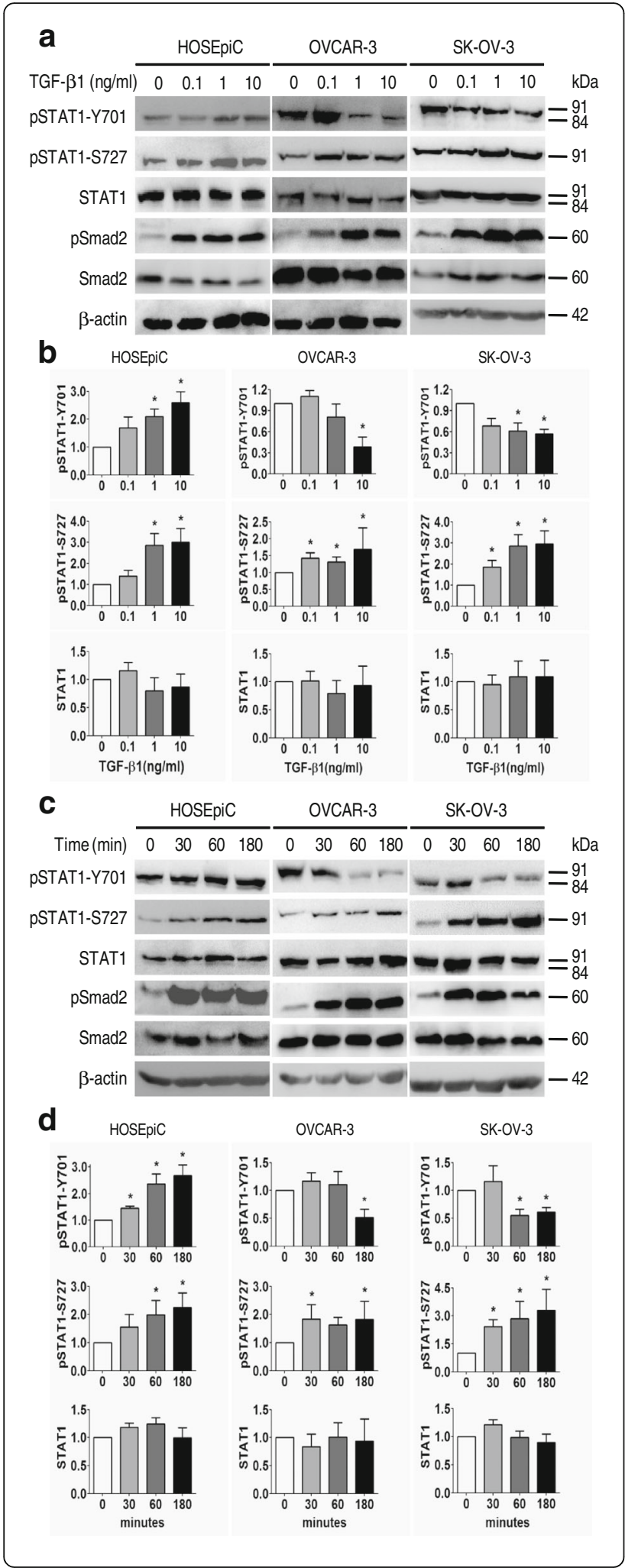

Fig. 2 TGF- $\beta 1$ regulates the phosphorylation of STAT1 in ovarian surface epithelial cells. Dose-dependent $(\mathbf{a}, \mathbf{b})$ and time-course $(\mathbf{c}, \mathbf{d})$ studies of the effect of TGF- $\beta 1$ on STAT1 phosphorylation (pSTAT1) are shown. a Immunoblotting after cells treated with TGF- $\beta 1(0,0.1$, 1 , and $10 \mathrm{ng} / \mathrm{ml}$ ) for $24 \mathrm{~h}$. $\mathbf{b}$ Densitometry analysis of the gels in (a). c Immunoblotting after cells treated with TGF- $\beta 1$ (10 ng/ml) for 30, 60, and $180 \mathrm{~min}$. d Densitometric analysis of the gels in (c). The phosphorylation of Smad2 (pSamd2) is increased after TGF- $\beta 1$ treatment, indicating the responsiveness of cells to TGF- $\beta 1$. Data are represented as the mean \pm SEM of the ratio of pSTAT1/total STAT1 and total STAT1/ $\beta$-actin. $\mathrm{n}=3$ independent experiments; ${ }^{*}, P<0.05$ compared to untreated cells

the mRNA of STAT1 $\alpha$ and total STAT1 was significantly increased in ovarian malignant tumors (Fig. 1c). Immunoblotting showed that STAT $1 \alpha(91 \mathrm{kDa})$ and STAT1 $\beta(84 \mathrm{kDa})$ were significantly increased in malignant tumors (Fig. 1d and e).

\section{STAT1 $\alpha$ is activated by the TGF- $\beta$ signaling pathway}

First, we compared the endogenous expression of STAT1 between non-tumorous ovarian epithelial cell line HOSEpiC and ovarian cancer cell lines OVCAR-3 and SK-OV-3. A steady-state level of STAT1 $\alpha$, STAT1 $\beta$, and total STAT1 mRNA was detected by qRT-PCR using specific primers (shown in Additional file 1: Table S1). We found that the expression of STAT $1 \alpha$, STAT1 $\beta$, and total STAT1 mRNA was higher in ovarian cancer cells (OVCAR-3 and SK-OV-3) than in non-tumorous cells (HOSEpiC) (Additional file 2: Figure S2a). Similar to mRNA, the protein expression level of total STAT1 was significantly higher in OVCAR-3 and SK-OV-3 cells than in HOSEpiC cells detected by immunoblotting (Additional file 2: Figure S2b). A higher level of pSTAT1-Y701 and pSTAT1-S727 was observed in OVCAR-3 and SK-OV-3 cells, respectively, compared with HOSEpiC cells (Additional file 2: Figure S2c).

Next, we examined if TGF- $\beta 1$ affects the activation status of STAT1 since in a pilot study we found that TGF- $\beta 1$ increased pSTAT1-S727 (active STAT1 $\alpha$ ), while decreased pSTAT1-Y701, in OVCAR-3 cells (Additional file 2: Figure S3). In a dose-dependent study with TGF- $\beta 1$ treatment for $24 \mathrm{~h}$, we found that the phosphorylation of STAT1 on Y701 residue was significantly decreased $(P<0.05)$ in EOC cells (OVCAR-3 and SK-OV-3), while it was significantly increased $(P<0.05)$ in HOSEpiC cells, the non-tumorous human ovarian surface epithelial cells (Fig. 2a and b). Importantly, the phosphorylation of STAT1 on S727 residue, which represents an active form of STAT1 $\alpha$, was significantly increased $(P<0.05)$ in all three epithelial-type cell lines after TGF- $\beta 1$ treatment (Fig. $2 \mathrm{a}$ and $\mathrm{b}$ ). In a time-course study with a constant dose $(10 \mathrm{ng} / \mathrm{ml})$ of TGF- $\beta 1$, we also observed that the phosphorylation of STAT1 on Y701 was significantly increased $(P<0.05)$ in HOSEpiC 
cells, but decreased $(P<0.05)$ in OVCAR-3 and SK-OV3 cells, and that on $\mathrm{S} 727$ was significantly increased $(P<$ 0.05 ) in all three cell lines (Fig. $2 c$ and d). TGF- $\beta 1$ did not affect total-STAT1 in all investigated ovarian surface epithelial cells. Phosphorylation of Smad2 was used to validate the activation of TGF- $\beta$ signaling upon stimulation with TGF- $\beta 1$ and an increase in phospho-Smad2 after TGF- $\beta 1$ treatment indicates the responsiveness of these cells to TGF- $\beta 1$.

Subsequently, we verified our results with an alternate strategy by blocking TGF- $\beta$ signaling in ovarian surface epithelial cells with a T $\beta R I$ specific inhibitor SB-431542. Cells were pretreated with $10 \mu \mathrm{M} \mathrm{SB}-431542$ for $30 \mathrm{~min}$, followed by treatment with $10 \mathrm{ng} / \mathrm{ml}$ TGF- $\beta 1$ for $24 \mathrm{~h}$. The inhibitor treatment clearly and significantly $(P<0$. 05) abolished the effects of TGF- $\beta 1$ on STAT1 phosphorylation on Y701 and S727 sites (Fig. 3a and b). Thus, our data demonstrated that the phosphorylation and activation of STAT1 can be mediated by the TGF- $\beta$ signaling pathway and may be a consequence of the direct interaction of STAT1 with TGF- $\beta$ receptors after TGF- $\beta 1$ stimulation.
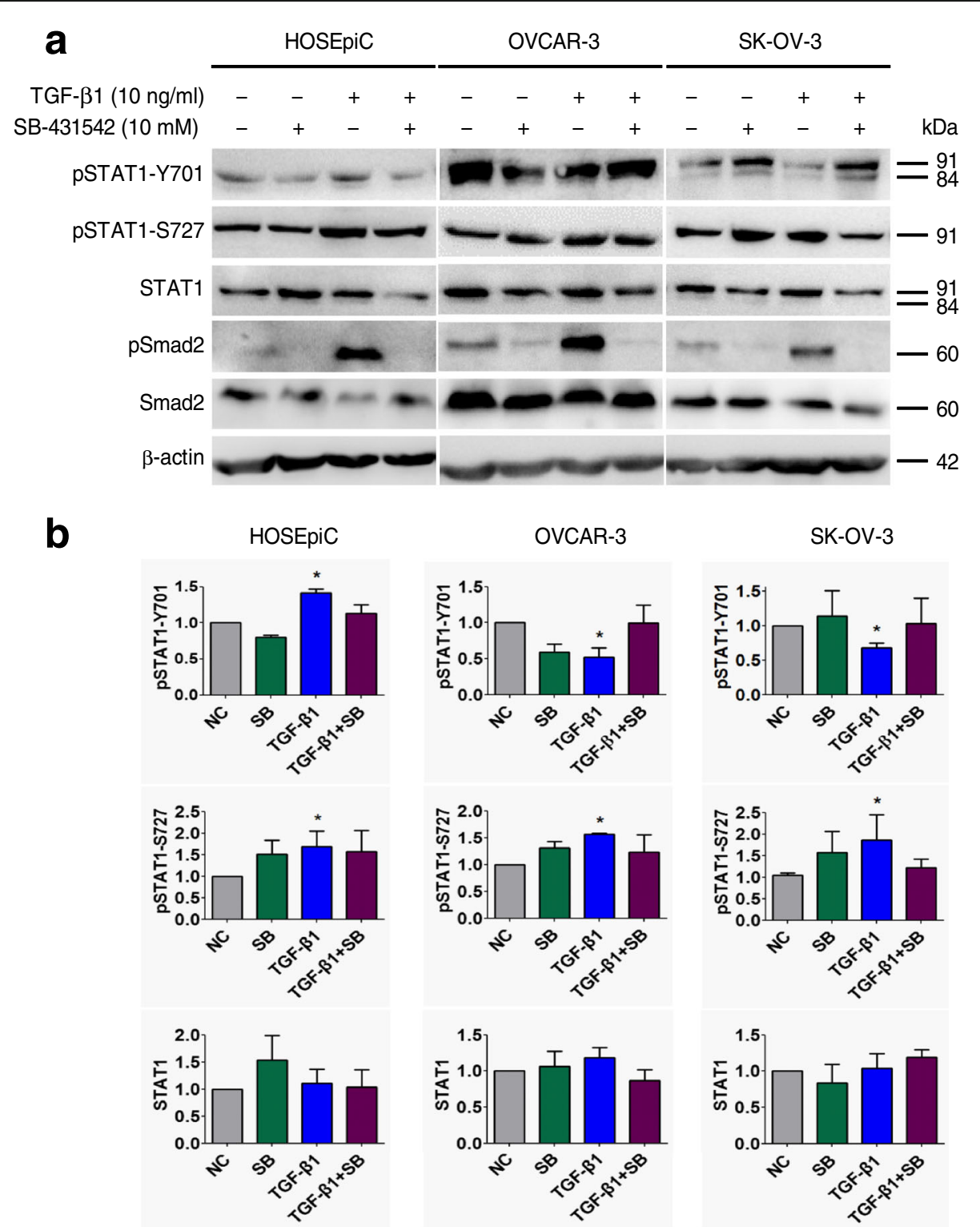

Fig. 3 Inhibition of TGF- $\beta$ receptor kinase blocks the effect of TGF- $\beta$ on STAT1 phosphorylation in ovarian surface epithelial cells. Cells were pretreated with $10 \mu \mathrm{M}$ TRRI inhibitor SB-431542 for $30 \mathrm{~min}$, followed by $10 \mathrm{ng} / \mathrm{ml}$ of TGF- $\beta 1$ treatment for $24 \mathrm{~h}$. a Immunoblotting after cells treated with SB-431542 and/or TGF- $\beta 1$. b Densitometric analysis of the gels in (a). The responsiveness of cells to TGF- $\beta 1$ was confirmed by the detection of pSmad2. Data are represented as the mean \pm SEM of the ratio of PSTAT1 over total STAT1 or total STAT1 over $\beta$-actin. NC, non-treated control; SB, SB-431542; $n=3$ independent experiments; ${ }^{*}, P<0.05$ compared to NC 
STAT1 $\alpha$ and STAT1 $\beta$ interact with TGF- $\beta$ type I and type II receptors

In order to assess STAT $1 \alpha / \beta$ and TGF- $\beta$ receptor interaction in vitro, we used HEK-293 T cells and transiently transfected them with myc-tagged STAT $1 \alpha /$ STAT $1 \beta$ and co-transfected them with HA-tagged ALK1/ALK5/TßRII plasmid vectors. Co-IP was performed with anti-myc or anti-HA antibody. The bound TGF- $\beta$ receptors or STAT1 isoforms were detected with anti-HA or anti-myc IB respectively. We found that both STAT $1 \alpha$ and STAT1 $\beta$ interact with ALK1, ALK5, and TßRII receptors (Fig. 4a and $b)$. The overexpression of STAT $1 \alpha$, STAT $1 \beta$, and receptor proteins was validated by IB (Fig. $4 \mathrm{c}$ and d).
Interaction of STAT1 with TGF- $\beta$ receptors is mediated by TGF- $\beta 1$

To determine whether TGF- $\beta 1$ affects the complex of STAT1 and TGF- $\beta$ receptors, HEK-293 T cells were co-transfected with STAT1 $\alpha$ or STAT1 $\beta$ and ALK1, ALK5, or T $\beta$ RII plasmids, followed by $10 \mathrm{ng} / \mathrm{ml}$ of TGF- $\beta 1$ treatment. Co-IP assay revealed that TGF- $\beta 1$ enhanced STAT1 $\alpha$ and STAT1 $\beta$ interaction with ALK1 (Fig. 5a and b). Interestingly, TGF- $\beta 1$ suppressed STAT $1 \alpha$, while enhanced STAT $1 \beta$, interaction with ALK5, the main type I receptor of TGF- $\beta$ (Fig. $5 \mathrm{c}$ and $\mathrm{d}$ ). Furthermore, TGF- $\beta 1$ suppressed STAT $1 \alpha$ and STAT1 $\beta$ interaction with T $\beta$ RII (Fig. 5e and f). These
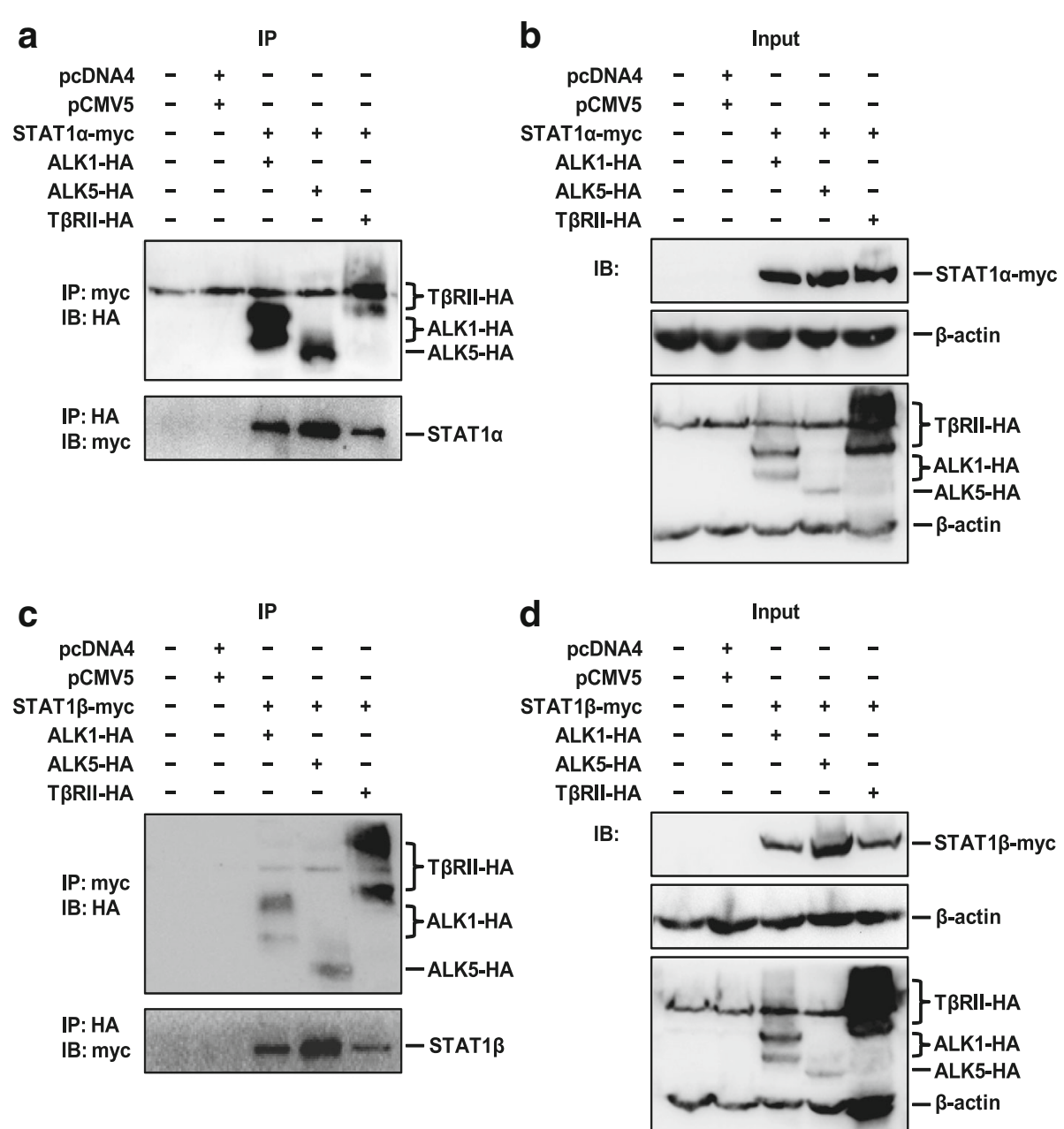

Fig. 4 STAT1 interacts with the TGF- $\beta 1$ receptor. HEK-293 T cells were transiently co-transfected with STAT1a-myc or STAT1 $\beta$-myc and ALK1-HA, ALK5-HA or TRRII-HA plasmids and incubated for $48 \mathrm{~h}$. a Interaction of STAT1a with receptors detected by immunoprecipitation (IP) with anti-myc antibody for STAT1a, followed by immunoblotting (IB) with anti-HA antibody for receptors (upper panel), or IP with anti-HA antibody for receptors, followed by IB with anti-myc antibody for STAT1a (bottom panel). b IB using antibodies specific to $\beta$-actin, myc for STAT1a, and HA for receptors. c Interaction of STAT1 $\beta$ with receptors detected by IP with anti-myc antibody for STAT1 $\beta$, followed by IB with anti-HA antibody for receptors (upper panel), or vice versa (bottom panel). $\mathbf{d}$ IB using antibodies specific to $\beta$-actin, myc for STAT1 $\beta$, and HA for receptors. pcDNA4 and pCMV5 are two empty vectors used as negative controls. Each experiment is repeated at least once. Representative images are shown. STAT1 a-myc, 93 kDa; STAT1 $\beta-$ myc, 86 kDa; ALK1-HA, 58-69 kDa; ALK5-HA, 53 kDa; TRRII-HA, 71-80 kDa 


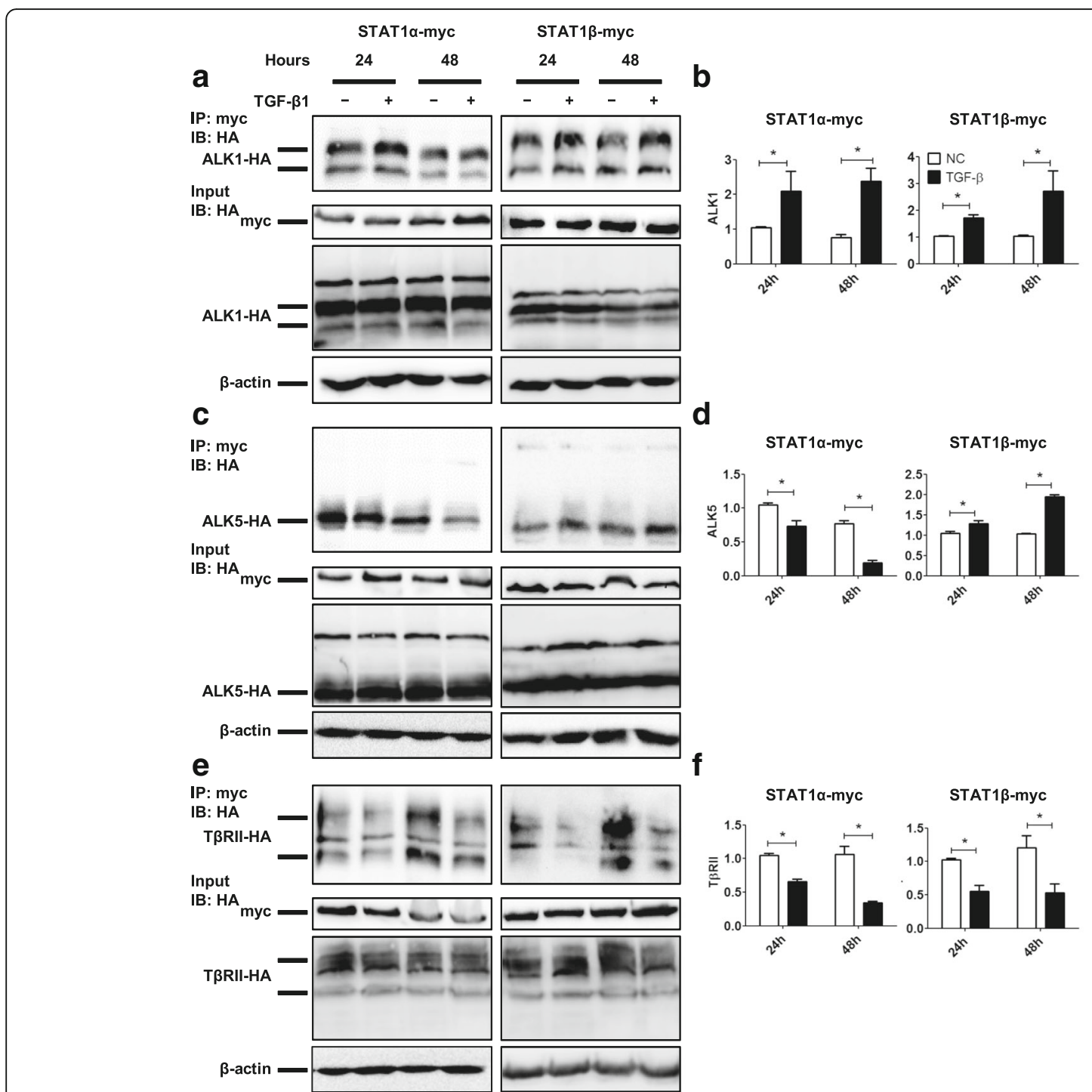

Fig. 5 TGF- $\beta 1$ regulates the interaction of STAT1a/STAT1 $\beta$ with ALK1/ALK5/T RRII. HEK-293 T cells were transiently co-transfected with STAT1a-myc or STAT1 $\beta$-myc and ALK1-HA, ALK5-HA or T $\beta R I I-H A$ plasmids in the absence or presence of TGF- $\beta 1$ (10 ng/ml) for 24 and 48 h. a Immunoprecipitation (IP) with anti-myc antibody for STAT1a-myc or STAT1 $\beta$-myc and immunoblotting (IB) with anti-HA antibody for ALK1-HA. Cell lysates of input samples were used for detecting the expression of STAT1-myc, ALK1-HA, and $\beta$-actin. $\mathbf{b}$ Densitometric and semi-quantitative analyses of the gels of IP in (a). $\mathbf{c}$ IP with anti-myc antibody for STAT1 a-myc or STAT1 $\beta$-myc and IB with anti-HA antibody for ALK5-HA. Cell lysates of input samples were used for detecting the expression of STAT1-myc, ALK5-HA, and $\beta$-actin. $\mathbf{d}$ Densitometric and semi-quantitative analyses of the gels of IP in (c). e IP with anti-myc antibody for STAT1a-myc or STAT1 $\beta$-myc and IB with anti-HA antibody for TBRII-HA. Cell lysates of input samples were used for detecting the expression of STAT1-myc, TRRII-HA, and $\beta$-actin. $\mathbf{f}$ Densitometric and semi-quantitative analyses of the gels of IP in (e). $n=3$ independent experiments; ${ }^{*}, P<0.05$

data indicate that TGF- $\beta 1$ may mediate the association and dissociation of STAT $1 \alpha / \beta$ with T $\beta$ RI/T $\beta$ RII receptors.

\section{STAT1 inhibits the TGF- $\beta$ signaling pathway}

In order to examine the significance of STAT1 interaction with TGF- $\beta$ receptors, we performed overexpression or knockdown of STAT $1 \alpha / \beta$ in ovarian cancer cells (SK-OV-3) and examined the status of the TGF- $\beta$ signaling pathway. We found that pSmad2 was increased after $10 \mathrm{ng} / \mathrm{ml}$ TGF- $\beta 1$ treatment for $24 \mathrm{~h}$, indicating that the TGF- $\beta$ signaling pathway was intact in SK-OV3 cells (Fig. $6 \mathrm{a}$ and b). However, a significant inhibition of Smad2 phosphorylation was observed in STAT1 $\alpha$ or STAT1 $\beta$ expressing cells even when the cells were stimulated with TGF- $\beta 1$ (Fig. 6a and b). On the other hand, knockdown of endogenous STAT1 in SK-OV-3 cells using STAT1-siRNA resulted in a significant increase of TGF- 31 -induced Smad2 phosphorylation (Fig. $6 \mathrm{c}$ and d). These data indicate that STAT1 inhibits the TGF- $\beta$ signaling pathway. 


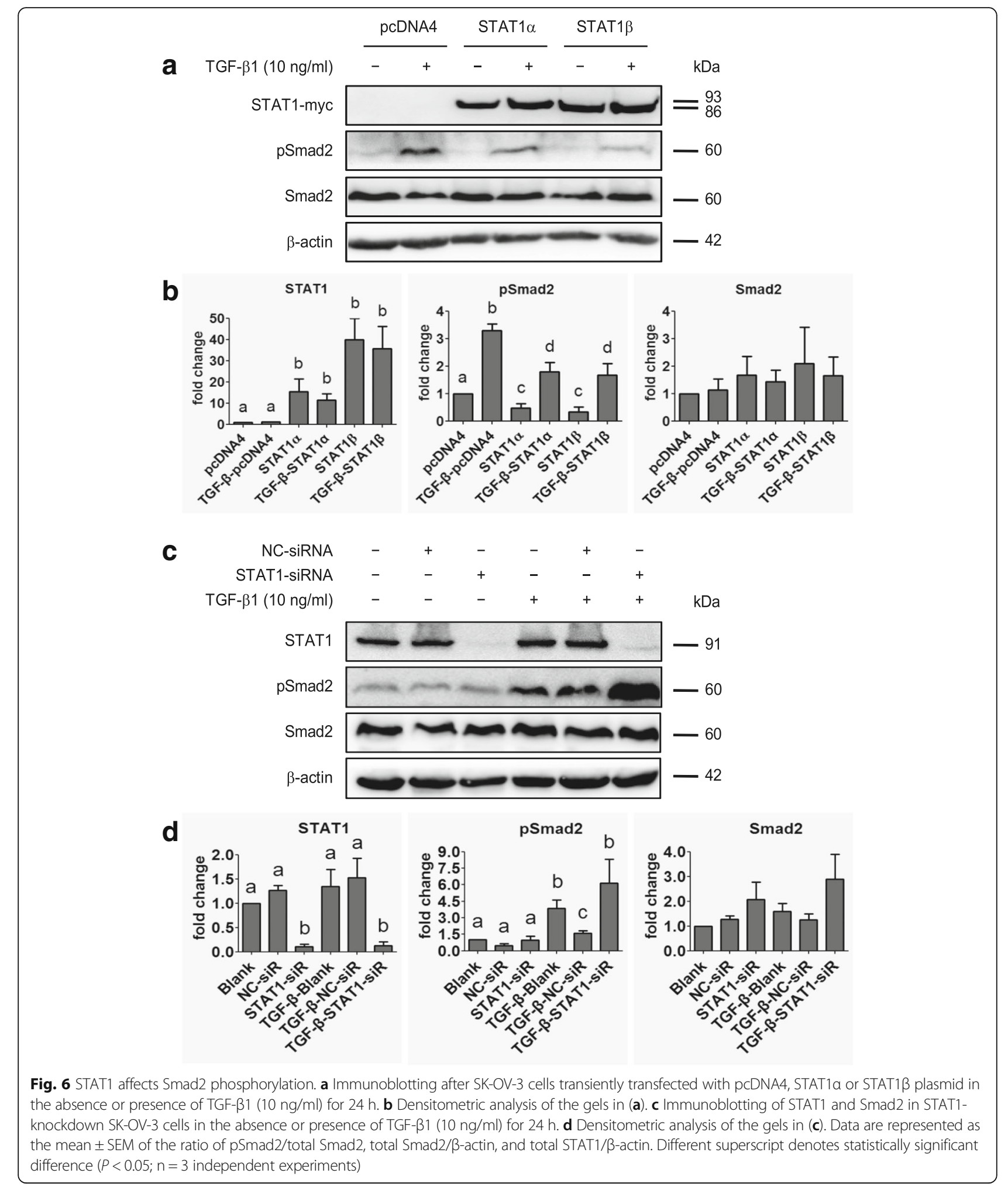

\section{STAT1 promotes EOC cell proliferation, migration, and} invasion

To investigate the role of STAT1 on cell behavior in ovarian cancer cells, the gain-of-function and loss-of- function approaches were applied. STAT $1 \alpha$ or STAT1 $\beta$ was overexpressed using STAT $1 \alpha-$ myc or STAT $1 \beta-$ myc plasmids in HOSEpiC, OVCAR-3 and SK-OV-3 cells in the presence or absence of $10 \mathrm{ng} / \mathrm{ml}$ of TGF- $\beta 1$ for $48 \mathrm{~h}$. 
a

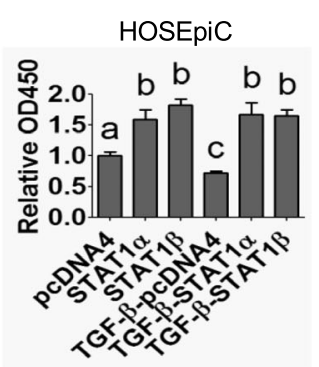

b
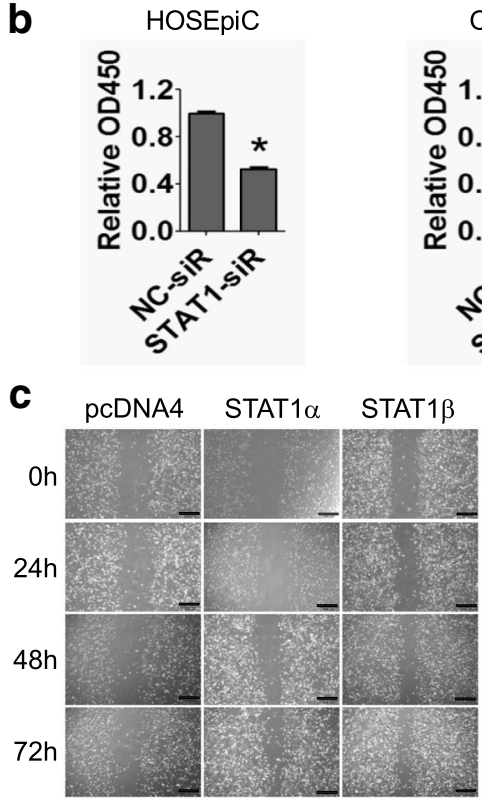

d
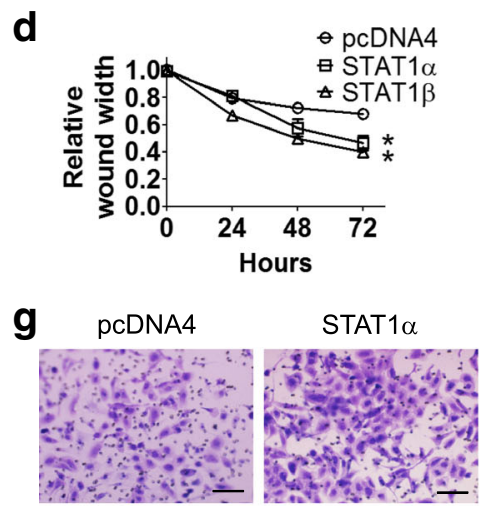

i

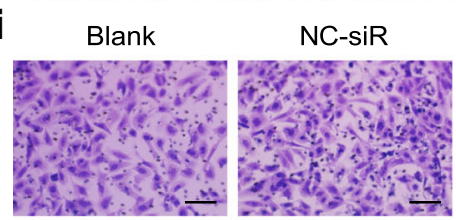

OVCAR-3
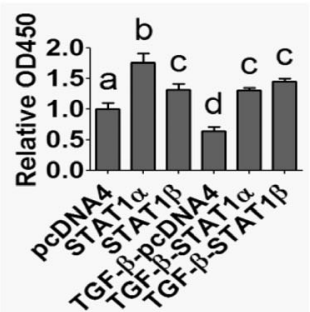

OVCAR-3

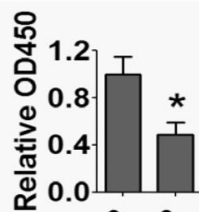

\& 8

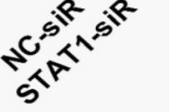

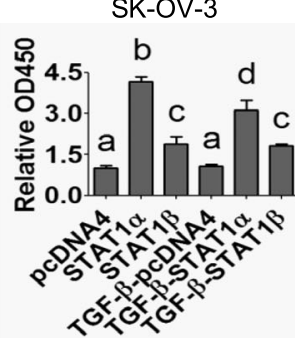

SK-OV-3

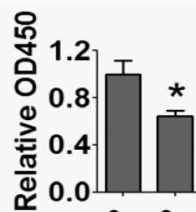

\& \&
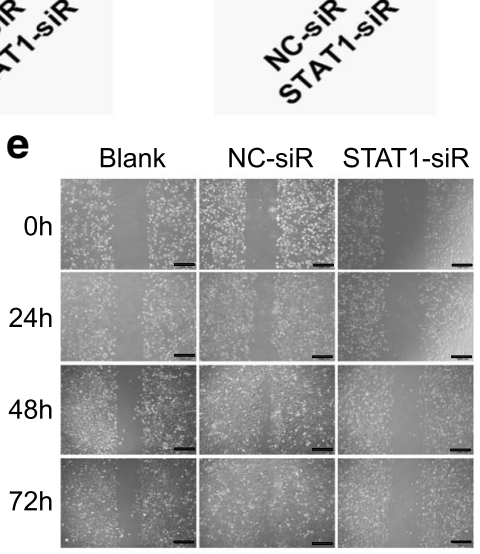

f

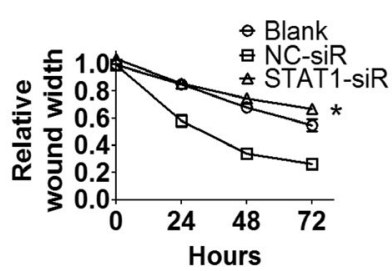

STAT1 $\beta$

h

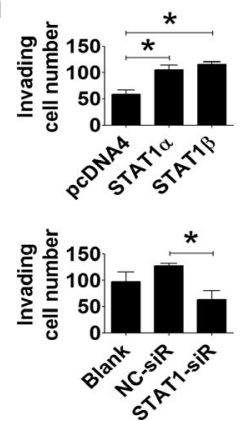

Fig. 7 (See legend on next page.) 


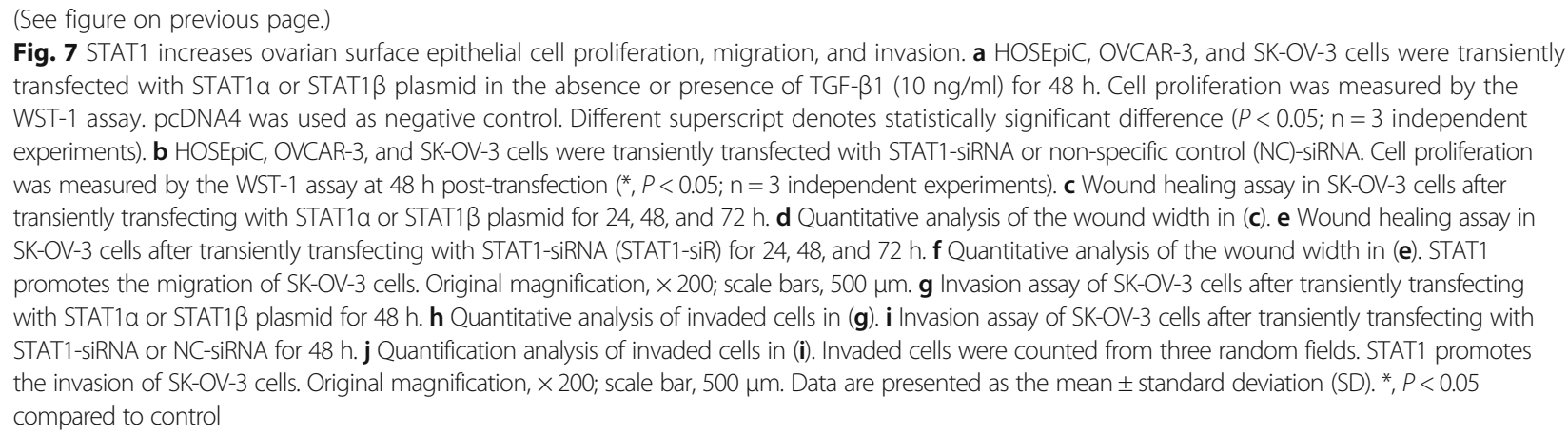

Cell proliferation was analyzed with WST-1 assay which showed that both STAT $1 \alpha$ and STAT1 $\beta$ significantly increased cell proliferation in all investigated cell lines $(P<0.05)$, while TGF- $\beta 1$ inhibits it in HOSEpiC and OVCAR-3 cells but not in SK-OV-3 cells (Fig. 7a). Importantly, TGF- $\beta 1$ failed to inhibit cell proliferation in STAT $1 \alpha$ or STAT $1 \beta$ overexpressing HOSEpiC cells and OVCAR-3 cells (Fig. 7a). On the other hand, the siRNA mediated knockdown of endogenous STAT1 resulted in a decrease of cell proliferation in all three cell lines (Fig. 7b). These data suggest that STAT1 promotes ovarian surface epithelial cell proliferation and blocks the inhibitory effect of TGF- $\beta$ on cell proliferation.

Using the same strategy of STAT1 overexpression and knockdown we assessed the effect of STAT1 $\alpha$ and STAT1 $\beta$ on SK-OV-3 cell migration using wound healing and cell invasion using Matrigel-transwell invasion assays. Overexpression of STAT1 $\alpha$ and STAT1 $\beta$ significantly increased $(P<0.05)$, and the suppression of STAT1 significantly decreased $(P<0.05)$, cell migration (Fig. 7c-f) and invasion (Fig. 7g-j) compared with their respective controls.

\section{Discussion}

The current study demonstrated for the first time that STAT $1 \alpha$ and STAT $1 \beta$ directly interact with TGF- $\beta$ receptors (ALK1/ALK5/T $\beta$ RII) and that the phosphorylation of STAT1 on Y701 and S727 is mediated by TGF- $\beta 1$. Furthermore, the overexpression or knockdown of STAT1 influences TGF- $\beta 1$-induced Smad2 phosphorylation and affects EOC cell proliferation, migration, and invasion. We convince that the crosstalk between two pathways initiates at the receptor level.

STAT1 is a transcriptional factor which mediates responses to all types of IFNs and regulates a variety of cellular activities [22], whereas the impairment of TGF- $\beta$ signaling has been found in various diseases, including cancer [23]. Although the interference between STAT1 and TGF- $\beta$ signaling has been reported previously, all data indicate that the crosstalk between these two pathways is the downstream event of receptor activation.
Furthermore, no exact mechanism of interference from each other is explored and the physical interaction of STAT1 with the signaling components of TGF- $\beta$ is never hypothesized. Using a high-throughput luminescencebased mammalian interactome mapping technology we have recently reported that STAT1 might interact with the TGF- $\beta$ type I and type II receptors [20]. The present study verified that STAT $1 \alpha / \beta$ indeed bind to T $\beta$ RII/T $\beta$ RI (ALK1 and ALK5) and negatively regulates TGF- $\beta$ signaling.

We consistently observed that TGF- $\beta 1$ induced STAT1 phosphorylation on Y701 and S727 in non-tumorous cells. In cancerous cells, however, TGF- $\beta 1$ induced STAT1 phosphorylation on S727 only (specific to STAT1 $\alpha$ form) and inhibits STAT1 phosphorylation on Y701 (specific to both STAT $1 \alpha$ and STAT1 $\beta$ forms). These data suggest that, besides IFNs, TGF- $\beta 1$ also modulates the STAT1 signaling pathway. Interestingly, the binding status of STAT $1 \alpha$ and STAT $1 \beta$ with ALK5, the main type I receptor of TGF- $\beta$, was different between non-cancerous and cancerous cells upon the administration of a ligand TGF$\beta 1$. It might depend on the certain circumstances. We hypothesize that there is a homeostasis function of STAT $1 \alpha$ and STAT $1 \beta$ in the normal situation, which TGF- $\beta 1$ activates both sites (Y701 and S727); whereas there is abnormal higher level of STAT1 in a tumor cell, which TGF- $\beta 1$ increases the phosphorylation of STAT1 at S727 site (STAT1 $\alpha)$ and decreases the phosphorylation of STAT1 at Y701 site (STAT1 $\alpha / \beta)$. TGF- $\beta$-mediated STAT1 phosphorylation and activation may be cell-type specific and may reflect a molecular shift in tumorigenesis. Similar to our finding, it has been shown that TGF- $\beta$ inhibits the activation and phosphorylation of STAT1 on Y701 induced by insulin-like growth factor binding protein-3 (IGFBP-3) in mesenchymal chondroprogenitor cells [24]. TGF- $\beta 1$ also inhibits IFN- $\gamma$-induced phosphorylation of STAT1 on Y701 and S727 in glial cells from rat brain [25]. However, none of these studies show that the phosphorylation of STAT1 is a consequence of its binding to the TGF- $\beta$ receptor. The current study provides conceivable evidence that an increase of STAT1 phosphorylation on S727, similar to Smad2 phosphorylation, can be detected 


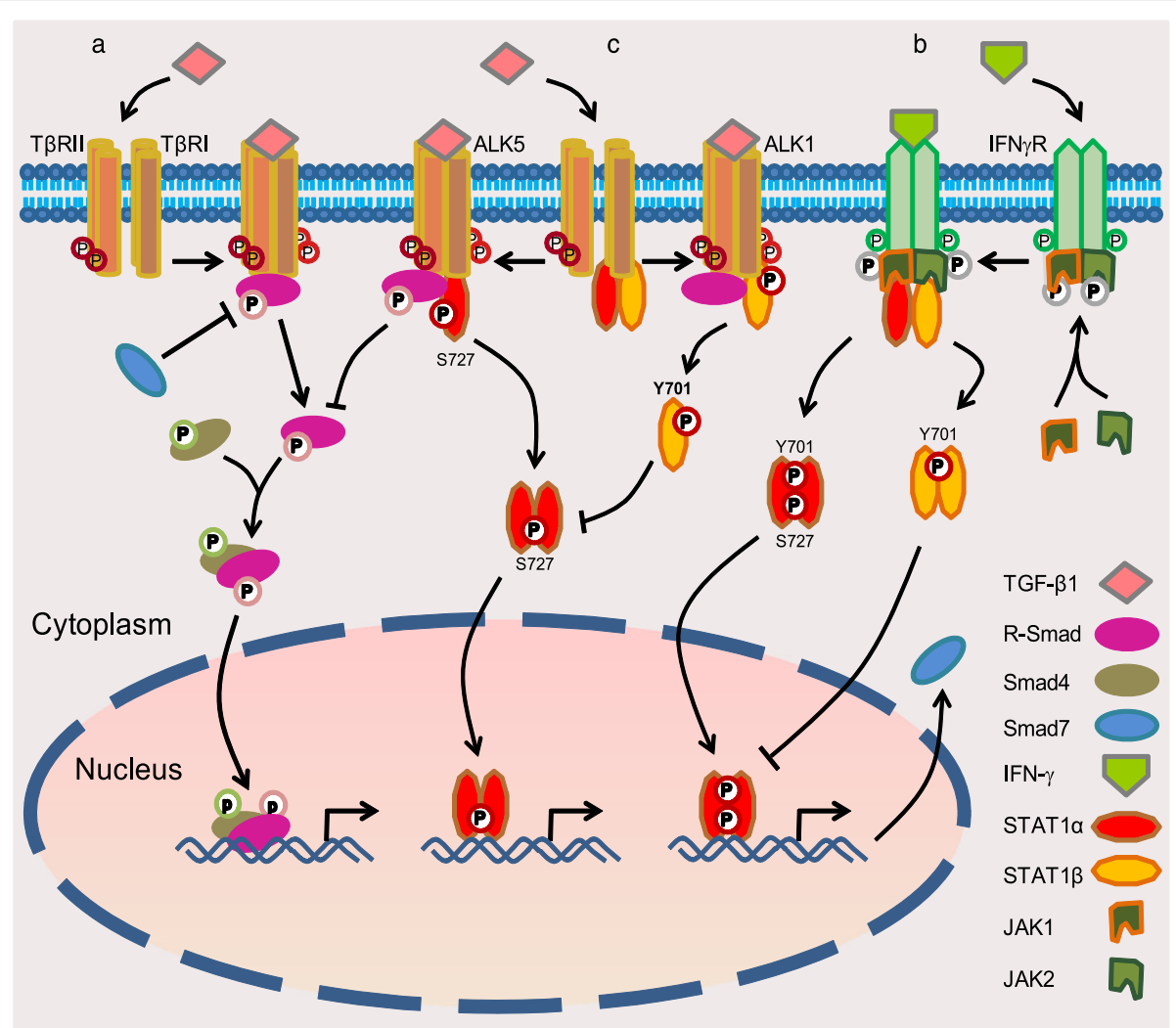

Fig. 8 A schematic of the model of crosstalk between STAT1 and TGF- $\beta$ signaling pathways. a The canonical signaling pathway of TGF- $\beta$ : upon

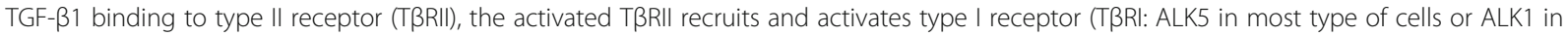
endothelial cells). The activated receptor kinases then phosphorylate R-Smads such as Smad2/3 (by ALK5) and Smad1/5/8 (by ALK1). Activated R-Smads form the complex with Smad4 and translocate to the nucleus where they regulate target genes $[12,36]$. $\mathbf{b}$ The canonical signaling pathway of STAT1: upon IFN- $\gamma$ binding to its receptor, JAKs are phosphorylated and activated each other. The activated JAKs along with the intracellular tail of receptor recruit and activate STAT1 by the phosphorylation of STAT1 on Y701 and/or S727, which promotes them to dimerize and enter the nucleus where they regulate gene expression [7, 37], e.g. gene Smad7. Protein Smad7 prevents R-Smad interaction with TGF- $\beta$ receptor [8]. Overexpression of STAT1 $\beta$ inhibits STAT1a activity to maintain the balance between two isoforms [26]. c The crosstalk of the STAT1 and TGF- $\beta$ signaling pathways: STAT1 constitutively interacts with T $\beta R I I / T \beta R I$ (either ALK5 or ALK1 based on cell type). Upon TGF- $\beta 1$ binding to TRRII/ALK5, the receptor-complex increases the phosphorylation of STAT1 on S727 (the active form of STAT1a). The activated STAT1 then dissociates itself from TBRII/ALK5 complex and executes its mission of transcription factor. On the other hand, STAT1 protein is increased in ovarian cancer cells and binds to TGF- $\beta$ receptors. Overexpressed STAT1 suppresses TGF- $\beta$-induced Smad 2 phosphorylation and blocks, at least in part, the TGF- $\beta$ signaling pathway (current work)

within a short time (30 min) upon TGF- $\beta 1$ stimulation, indicating that this process is associated with TGF- $\beta$ receptor binding after the cytokine treatment.

Our study has shown that the status of the association or dissociation of STAT1/T $\beta R I / T \beta R I I$ complex is altered after TGF- $\beta 1$ treatment. Classically, the activated STAT1 should dissociate from the TRRII/ALK5 complex, dimerize and translocate to the nucleus. However based on our co-immunoprecipitation data we speculate that the interaction between STAT $1 \alpha$ and TGF- $\beta$ receptor is not transient and that STAT $1 \alpha$ constitutively binds to the TGF- $\beta$ receptor, and blocks Smad phosphorylation and hence the downstream TGF- $\beta$ signaling pathway. The phosphorylation of STAT $1 \alpha$ by TGF- $\beta 1$ leads to its activation and the dissociation of STAT $1 \alpha$ from T $\beta$ RII/ ALK5 receptor complex that releases the blockage and, in turn, increases the phosphorylation of Smad2, executing TGF- $\beta$ signal transduction in ovarian cancer cells. Furthermore, the balance between STAT $1 \alpha$ and STAT1 $\beta$ is important in ovarian tumorigenesis. It has been showed the overexpression of STAT1 $\beta$ can inhibit the phosphorylation of STAT $1 \alpha$ as well as the DNA-binding and transcriptional activities in B lymphocytes [26], indicating that the altered levels of the STAT1 isoforms may affect the pathophysiological processes. In support of our data that $\mathrm{STAT}^{-/-}$mice had high activation of the TGF- $\beta$ signaling pathway during liver fibrosis [27], knockdown of STAT1 enhances TGF- $\beta 1$-induced phospho-Smad2, whereas overexpression of STAT1 suppresses TGF- $\beta 1$-induced phospho-Smad2, strongly pointing toward the influence of STAT1 on TGF- $\beta$ signaling pathway. 
With respect to tumorigenesis both STAT1 and TGF$\beta 1$ present controversial roles. STAT1 has been reported for its tumor suppressive as well as tumor promoting functions [28], whereas TGF- $\beta$ inhibits cell proliferation at an early stage and promotes invasion and metastasis at the later stage of cancer [29]. TGF- $\beta$-mediated STAT1 activation via STAT $1 \alpha$ phosphorylation may result in the promotion of tumorigenesis. The current study showed that the expression level of STAT1 was higher in ovarian cancer cells (OVCAR-3 and SK-OV-3) than noncancerous ovarian cells (HOSEpiC). High level of STAT1 was also observed in patients with high-grade serous EOC. The overexpression of STAT1 in ovarian cancer may result in the tumorigenic effect of TGF- $\beta$ signaling and therefore partially explains the controversial behavior of TGF- $\beta$ in tumorigenesis. Similar to the results reported previously in endometrial cancer cells [30], our study demonstrated that the elevation of STAT1 expression promotes while its knockdown inhibits EOC cell proliferation, migration, and invasion.

In the present study, we found overexpression of STAT1 at both mRNA and protein levels in human epithelial-type ovarian borderline and malignant tumor tissues. High level of STAT1 was found in ovarian serous malignant tumors rather than in mucinous tumors, indicating that it is a tissue biomarker at least and is tumortype specific. STAT1 has been recently identified as a drug resistance biomarker in ovarian cancer [31]. It has been reported that STAT1 is a potential indicator predicting chemoresistance in EOC $[32,33]$. Activating the FAK/STAT1 signaling pathway induces a malignant potential in ovarian epithelium [34] and targeting this signaling pathway is a good therapeutic strategy for ovarian cancer [35].

\section{Conclusions}

STAT1 is a tissue biomarker of serous-type EOC. Overexpression of STAT1 inhibits, whereas a decrease of STAT1 enhances, TGF- $\beta$-mediated suppression of cell proliferation, migration, and invasion. STAT1 directly interacts with T $\beta R I I / T \beta R I$ (either ALK5 or ALK1 based on cell type) and is activated by TGF- $\beta 1$, while TGF- $\beta$ signaling is blocked by STAT1 as a consequence of this interaction (Fig. 8). These data unveil a new insight into the molecular mechanisms of crosstalk between the STAT1 and TGF- $\beta$ signaling pathways and suggest that STAT1 is a potential therapeutic target for EOC treatment.

\section{Additional files}

Additional file 1: Table S1. PCR primer and siRNA sequence used in experiments. Table S2. Comparison of pSTAT1-Y701, pSTAT1-S727, and STAT1 immunostaining in the ovarian tissues. Table S3. The expression of pSTAT1-Y701, pSTAT1-S727, and STAT1 in human ovarian tissues. (DOCX $50 \mathrm{~kb}$ )

Additional file 2: Figure S1. STAT1 expression in human epithelial-type ovarian tumors. Tissue microarray shows the immunohistochemical $(\mathrm{IHC})$ staining of pSTAT1-Y701, pSTAT1-S727, and total STAT1 in serous, mucinous, endometrioid, transitional cell, and metastatic tumors. Figure S2. STAT1 expression in ovarian surface epithelial cells. a STAT1 mRNA expression detected by quantitative RT-PCR. b STAT1 protein expression detected by immunoblotting. c Densitometric analysis of the gels. Figure S3. Effect of TGF- $\beta 1$ on the phosphorylation of STAT1. (DOCX 1304 kb)

\section{Abbreviations}

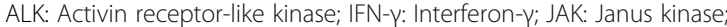
siRNA: small interfering RNA; STAT: Signal transducer and activator of transcription; TGF- $\beta$ : Transforming growth factor- $\beta$; T $\beta$ RI: TGF- $\beta$ type I receptor; T $\beta$ RII: TGF- $\beta$ type $\|$ receptor

\section{Acknowledgements}

We would like to think Dr. Jeffrey L. Wrana from Mount Sinai Hospital (Canada) and Dr. Michelle Letarte from The Hospital for Sick Children (Canada) for providing the plasmids of TGF- $\beta$ receptors.

\section{Funding}

This work was supported by grants from National Natural Science Foundation of China (81272880), Natural Science Foundation of Shanghai (17ZR1404100), Shanghai Municipal Commission of Health and Family Planning (201640287), and Science and Technology Commission of Shanghai Municipality (124119b1300) to GX and a grant from Committee of Science and Technology of Jinshan District (JSKJ-KTMS-2015-01) to XT. Xiaoling Tian is recipient of a postdoctoral fellowship from Fudan University.

\section{Authors' contributions}

XT conducted experiments, data analyses, figure generation and manuscript preparation. WG generated STAT1 plasmid constructs and participated in transfection experiments. LZ, WS, DZ and QL collected the samples, extracted RNA and protein, interpreted the patient data and analyzed data. WR performed pathological diagnosis and analysis. LN contributed to data analysis and manuscript writing. GX contributed to the experiment design, data analysis, figure generation, and manuscript writing. All authors read and approved the final manuscript.

Ethics approval and consent to participate

The study on human subjects was approved by the Ethics Committee of Jinshan Hospital, Fudan University (Reference \# 2013-019-01).

\section{Competing interests}

The authors declare that they have no competing interests.

\section{Publisher's Note}

Springer Nature remains neutral with regard to jurisdictional claims in published maps and institutional affiliations.

\section{Author details}

${ }^{1}$ Center Laboratory, Jinshan Hospital, Fudan University, 1508 Longhang Road, Shanghai 201508, People's Republic of China. ²Department of Oncology,

Shanghai Medical College, Fudan University, Shanghai 200032, China.

${ }^{3}$ Lunenfeld Tanenbaum Research Institute, Mount Sinai Hospital, Toronto, ON M5G 1X5, Canada.

Received: 25 March 2018 Accepted: 25 April 2018

Published online: 11 May 2018

References

1. Begitt A, Droescher M, Meyer T, Schmid CD, Baker M, Antunes F, Knobeloch KP, Owen MR, Naumann R, Decker T, Vinkemeier U. STAT1-cooperative DNA binding distinguishes type 1 from type 2 interferon signaling. Nat Immunol. 2014;15:168-76.

2. Kim HS, Lee MS. STAT1 as a key modulator of cell death. Cell Signal. 2007; 19:454-65. 
3. Ramana CV, Chatterjee-Kishore M, Nguyen H, Stark GR. Complex roles of Stat1 in regulating gene expression. Oncogene. 2000;19:2619-27.

4. Shuai K, Stark GR, Kerr IM, Darnell JE Jr. A single phosphotyrosine residue of Stat91 required for gene activation by interferon-gamma. Science. 1993;261: 1744-6.

5. Najjar I, Schischmanoff PO, Baran-Marszak F, Deglesne PA, Youlyouz-Marfak I, Pampin M, Feuillard J, Bornkamm GW, Chelbi-Alix MK, Fagard R. Novel function of STAT1 beta in B cells: induction of cell death by a mechanism different from that of STAT1alpha. J Leukoc Biol. 2008;84:1604-12.

6. Wen Z, Zhong Z, Darnell JE Jr. Maximal activation of transcription by Stat1 and Stat3 requires both tyrosine and serine phosphorylation. Cell. 1995;82:241-50.

7. O'Shea JJ, Schwartz DM, Villarino AV, Gadina M, Mclnnes IB, Laurence A. The JAK-STAT pathway: impact on human disease and therapeutic intervention. Annu Rev Med. 2015;66:311-28.

8. Ulloa L, Doody J, Massague J. Inhibition of transforming growth factor-beta/SMAD signalling by the interferon-gamma/STAT pathway. Nature. 1999;397:710-3.

9. Zhang S, Fei T, Zhang L, Zhang R, Chen F, Ning Y, Han Y, Feng XH, Meng A, Chen YG. Smad7 antagonizes transforming growth factor beta signaling in the nucleus by interfering with functional Smad-DNA complex formation. Mol Cell Biol. 2007;27:4488-99.

10. Chou JL, Chen LY, Lai HC, Chan MW. TGF-beta: friend or foe? The role of TGFbeta/SMAD signaling in epigenetic silencing of ovarian cancer and its implication in epigenetic therapy. Expert Opin Ther Targets. 2010;14:1213-23.

11. Nilsson EE, Skinner MK. Role of transforming growth factor beta in ovarian surface epithelium biology and ovarian cancer. Reprod BioMed Online. 2002;:5:254-8.

12. Shi Y, Massague J. Mechanisms of TGF-beta signaling from cell membrane to the nucleus. Cell. 2003;113:685-700

13. Huang $T$, David L, Mendoza V, Yang Y, Villarreal M, De K, Sun L, Fang X, Lopez-Casillas F, Wrana JL, Hinck AP. TGF-beta signalling is mediated by two autonomously functioning TbetaRl:TbetaRll pairs. EMBO J. 2011;30:1263-76.

14. Massague J. TGFbeta signalling in context. Nat Rev Mol Cell Biol. 2012;13: 616-30.

15. Orlova W, Liu Z, Goumans MJ, ten Dijke P. Controlling angiogenesis by two unique TGF-beta type I receptor signaling pathways. Histol Histopathol. 2011;26:1219-30.

16. Attisano L, Wrana JL. Signal transduction by the TGF-beta superfamily. Science. 2002;296:1646-7.

17. Miyazono K. TGF-beta signaling by Smad proteins. Cytokine Growth Factor Rev. 2000;11:15-22.

18. Gurram RK, Kujur W, Maurya SK, Agrewala JN. Caerulomycin a enhances transforming growth factor-beta (TGF-beta)-Smad3 protein signaling by suppressing interferon-gamma (IFN-gamma)-signal transducer and activator of transcription 1 (STAT1) protein signaling to expand regulatory T cells (Tregs). J Biol Chem. 2014;289:17515-28.

19. Reardon C, McKay DM. TGF-beta suppresses IFN-gamma-STAT1-dependent gene transcription by enhancing STAT1-PIAS1 interactions in epithelia but not monocytes/macrophages. J Immunol. 2007;178:4284-95.

20. Xu G, Barrios-Rodiles M, Jerkic M, Turinsky AL, Nadon R, Vera S, Voulgaraki D, Wrana JL, Toporsian M, Letarte M. Novel protein interactions with endoglin and activin receptor-like kinase 1: potential role in vascular networks. Mol Cell Proteomics. 2014;13:489-502.

21. Wang X, Gui L, Zhang Y, Zhang J, Shi J, Xu G. Cystatin B is a progression marker of human epithelial ovarian tumors mediated by the TGF-beta signaling pathway. Int J Oncol. 2014;44:1099-106.

22. Meissl K, Macho-Maschler S, Muller M, Strobl B. The good and the bad faces of STAT1 in solid tumours. Cytokine. 2017;89:12-20.

23. Colak S, Ten Dijke P. Targeting TGF-beta signaling in Cancer. Trends Cancer. 2017:3:56-71.

24. O'Rear L, Longobardi L, Torello M, Law BK, Moses HL, Chiarelli F, Spagnoli A. Signaling cross-talk between IGF-binding protein-3 and transforming growth factor-(beta) in mesenchymal chondroprogenitor cell growth. J Mol Endocrinol. 2005;34:723-37.

25. Herrera-Molina R, Flores B, Orellana JA, von Bernhardi R. Modulation of interferon-gamma-induced glial cell activation by transforming growth factor beta1: a role for STAT1 and MAPK pathways. J Neurochem. 2012;123: 113-23.

26. Baran-Marszak F, Feuillard J, Najjar I, Le Clorennec C, Bechet JM, DusanterFourt I, Bornkamm GW, Raphael M, Fagard R. Differential roles of STAT1alpha and STAT1 beta in fludarabine-induced cell cycle arrest and apoptosis in human B cells. Blood. 2004;104:2475-83.
27. Jeong WI, Park O, Radaeva S, Gao B. STAT1 inhibits liver fibrosis in mice by inhibiting stellate cell proliferation and stimulating NK cell cytotoxicity. Hepatology. 2006;44:1441-51.

28. Meissl K, Macho-Maschler S, Muller M, Strobl B. The good and the bad faces of STAT1 in solid tumours. Cytokine. 2015;

29. Derynck R, Akhurst RJ, Balmain A. TGF-beta signaling in tumor suppression and cancer progression. Nat Genet. 2001;29:117-29.

30. Kharma B, Baba T, Matsumura N, Kang HS, Hamanishi J, Murakami R, McConechy MM, Leung S, Yamaguchi K, Hosoe Y, et al. STAT1 drives tumor progression in serous papillary endometrial cancer. Cancer Res. 2014;74:6519-30.

31. Davidson B. Recently identified drug resistance biomarkers in ovarian cancer. Expert Rev Mol Diagn. 2016;16:569-78.

32. Au KK, Le Page C, Ren R, Meunier L, Clement I, Tyrishkin K, Peterson N, Kendall-Dupont J, Childs T, Francis JA, et al. STAT1-associated intratumoural TH1 immunity predicts chemotherapy resistance in high-grade serous ovarian cancer. J Pathol Clin Res. 2016;2:259-70.

33. Stronach EA, Alfraidi A, Rama N, Datler C, Studd JB, Agarwal R, Guney TG, Gourley C, Hennessy BT, Mills GB, et al. HDAC4-regulated STAT1 activation mediates platinum resistance in ovarian cancer. Cancer Res. 2011;11:4412-22.

34. Zhang L, Wang D, Jiang W, Edwards D, Qiu W, Barroilhet LM, Rho JH, Jin L, Seethappan V, Vitonis A, et al. Activated networking of platelet activating factor receptor and FAK/STAT1 induces malignant potential in BRCA1mutant at-risk ovarian epithelium. Reprod Biol Endocrinol. 2010;8:74.

35. Zhang L, Zou W. Inhibition of integrin beta1 decreases the malignancy of ovarian cancer cells and potentiates anticancer therapy via the FAK/STAT1 signaling pathway. Mol Med Rep. 2015;12:7869-76.

36. Schmierer B, Hill CS. TGFbeta-SMAD signal transduction: molecular specificity and functional flexibility. Nat Rev Mol Cell Biol. 2007;8:970-82.

37. Shuai K, Liu B. Regulation of JAK-STAT signalling in the immune system. Nat Rev Immunol. 2003;3:900-11.

\section{Ready to submit your research? Choose BMC and benefit from:}

- fast, convenient online submission

- thorough peer review by experienced researchers in your field

- rapid publication on acceptance

- support for research data, including large and complex data types

- gold Open Access which fosters wider collaboration and increased citations

- maximum visibility for your research: over $100 \mathrm{M}$ website views per year

At BMC, research is always in progress.

Learn more biomedcentral.com/submissions 